\title{
Occurrence of metabolic risk in schoolchildren using a noninvasive indicator: waist and height ratio

\author{
Arieli Fernandes Dias ${ }^{1}$, Caroline Brand ${ }^{1}$, Vanilson Batista \\ Lemes ${ }^{1}$, Adroaldo Cezar Araujo Gaya ${ }^{1}$, Anelise Reis Gaya ${ }^{1}$
}

\author{
Open acess \\ ${ }^{1}$ Universidade Federal do Rio \\ Grande do Sul (UFRGS). Programa \\ de Pós-Graduação em Ciências \\ do Movimento Humano. Grupo de \\ pesquisa Projeto Esporte Brasil \\ (PROESP-Br). Porto Alegre, Rio \\ Grande do Sul, Brasil. \\ Corresponding author: \\ ariieli_dias@hotmail.com
}

Manuscript received: April 2018 Manuscript accepted: October 2018

Version of record online: November 2018

\begin{abstract}
Introduction: Metabolic disorders in childhood and adolescence have been increasing considerably. Thus, the importance of performing an early diagnosis is emphasized.
\end{abstract}

Objective: To analyse the occurrence of metabolic risk using a non-invasive marker in schoolchildren.

Methods: This is a descriptive study with a quantitative approach, with random sample of 174 schoolchildren (70 boys and 104 girls) from 10 state high schools in the city of Passo Fundo, Rio Grande do Sul, Brazil. The height $(\mathrm{cm})$ was verified according to the procedures of the Brazilian Sport Project and the waist circumference $(\mathrm{cm})$ was measured with a flexible and inelastic tape measure. From this the waist-to-height ratio was calculated, which takes into account the proportion of abdominal fat by the individual's height, considering the cut-off point of Ashwell \& Hsieh. For data analysis we used descriptive and chi-square statistics.

Results: The metabolic risk of schoolchildren was $13.8 \%$, when stratified by sex, the occurrences were $11.4 \%$ for males and $15.4 \%$ for females, but there was no significant difference between the sexes $\left(X^{2}=0.54\right.$; $\mathrm{p}=0.45)$.

Conclusion: The use of non-invasive markers for the diagnosis of metabolic risk indicated a high occurrence of it in schoolchildren, with the girls presenting a higher risk. The use of this method is important because it allows the evaluation of a greater number of schoolchildren and the early identification of health risk. In addition to being a low-cost, easy-to-apply method.

Keywords: adolescents, anthropometry, health. 


\section{INTRODUCTION}

Obesity in childhood and adolescence has become a serious public health problem, reaching a high prevalence ${ }^{1}$. Excessive fat accumulation is often related to the occurrence of numerous metabolic disorders, such as changes in lipid profile, insulin resistance and arterial hypertension ${ }^{2}$. These abnormalities, when diagnosed together, characterize the metabolic syndrome (MS) ${ }^{3}$.

In addition, it is widely recognized that obesity, especially abdominal obesity, is associated with increased cardiovascular risk, type II diabetes mellitus and mortality ${ }^{4}$. For these reasons, the early diagnosis of the risk of developing MS is extremely relevant for clinical and pedagogical practice in the school context due to the potential that physical education has for promoting health through physical activity ${ }^{5,6}$.

In this perspective, anthropometric indicators are considered simple, non-invasive and low-cost methods that can be used to classify patients in general and schoolchildren at risk of developing metabolic disorders, as well as to evaluate the effectiveness of the interventions developed for this purpose ${ }^{7}$. In fact, several studies investigate the association between anthropometric indicators and cardiometabolic risk in different populations ${ }^{8-10}$.

Regarding anthropometric evaluation methods, Ashwell and Hsieh ${ }^{11}$ propose the use of the waist-toheight ratio (WHtR) as a simple and rapid screening tool for the identification of height-based abdominal fat, which can be used to assess the health risk of different populations. In addition, a systematic review indicated that WHtR and waist circumference (WC) were significant predictors of cardiometabolic risk, better than body mass index (BMI). In addition, it was pointed out that the WHtR may be a more effective clinical screening tool than $\mathrm{WC}^{12}$. In this sense, Ribeiro $\&$ Silva demonstrated that the sensitivity and specificity values for the use of the WHtR as an indicator of risk were higher when compared with WC and BMI.

It is important to use this easily applicable method to be used in the school environment, in order to identify the metabolic risk of adolescents. The objective is to analyze the occurrence of metabolic risk using a noninvasive marker in schoolchildren.

\section{METHODS}

This is a descriptive study with a quantitative approach. The population was composed of 15 public secondary schools in Passo Fundo - Rio Grande do Sul, Brazil, which corresponds to approximately 4,599 schoolchildren (according to the 7th Regional Education Coordination) - Rio Grande do Sul, Brazil).

The study sample was randomized. Considering the target population (4,599 students), a sampling error of $5 \%$, a ratio of $10 \%$ and a significance level of $95 \%$. The minimum sample size was 134 students, identified by the following equation ${ }^{13}$.

$$
n=Z a \cdot p \cdot q \cdot N / e^{2} \cdot(N-1)+Z \alpha^{2} \cdot p \cdot q
$$

In which:

$\mathrm{n}=$ sample size

$\mathrm{Z} \alpha=$ level of significance measured in unit of standard deviation

$\mathrm{p}=$ proportion of subjects in the population

$\mathrm{q}=100-\mathrm{p}$

$\mathrm{N}=$ population size

$\mathrm{E}=$ sampling error

In order to minimize possible sample losses due to measurement errors, non-compliance with the inclusion criteria, an increase of $30 \%$ was chosen, totaling 176 subjects. The selection took place in three moments. In the first, the city was divided into five regions (north, south, east, west and center), then schools were selected from each region. Of the 15 state schools in Passo Fundo, Rio Grande do Sul, Brazil, 10 were drawn by region. In the third moment, a high school class was drawn in each school.

All high school classes in the school raffle participated in the draw. All students of the drawnout class, within the required age range, were invited to participate in the study. The inclusion criteria considered were: a) to be enrolled in the high school of the public school system of the municipality; b) be within the age group of 14 to 18 years; and, c) present the informed consent form signed by a responsible person and the statement of assent expressing willingness to participate.

To assess the occurrence of metabolic risk through a noninvasive indicator, the WHtR was used, the ratio between waist measurement and height in centimeters. For this, was measured to WC by means of a flexible and inelastic metric tape (Cescorf) with resolution of $1 \mathrm{~mm}$. The measurement was performed between the midpoint between the lower border of the last rib and the iliac crest ${ }^{14}$. The height was measured using a metric tape fixed to the wall and extended from the bottom upwards, with the students kept upright with feet and trunk leaning against the wall. This measure was noted in centimeters to one decimal place and followed the standard procedure of the Projeto Esporte Brasil $^{15}$. These evaluations were performed by a group of previously trained researchers. The WHtR was categorized according to the cut-off point of Ashwell $\&$ Hsieh $^{11}$, being considered a risk zone values greater than or equal to 0.5 .

For the data treatment, a descriptive analysis was used, presenting the means, standard deviation, absolute and relative frequencies stratified by sex. In addition, the chi-square test was performed to verify if there was a difference between the sexes and the occurrence of metabolic risk. Data were tabulated and analyzed in SPSS for Windows software version 22.0. For inferential analysis, a significance level of 5\% and a test power of 0.85 were considered. The study was approved by the Ethics Committee in Research with Human Beings of the Federal University of Rio Grande do Sul, under opinion number 888.090. 


\section{RESULTS}

Of the 176 students, 174 ( 70 boys and 104 girls) aged 14 to 18 years were evaluated. This sample loss was due to being outside the age bracket considered. Table 1 shows the description of the characteristics of the sample.

The number of schoolchildren with metabolic risk was $11.4 \%$ (CI. 4.3\%-18.6\%) in boys and $15.4 \%$ $(9.6 \%-23.1 \%)$ in girls. at risk. There was no significant difference between the sexes $\left(\mathrm{X}^{2}=0.54, \mathrm{p}=0.45\right)$. In general, schoolchildren have $13.8 \%$ (CI. $8.6 \%-19 \%$ ) of metabolic risk.

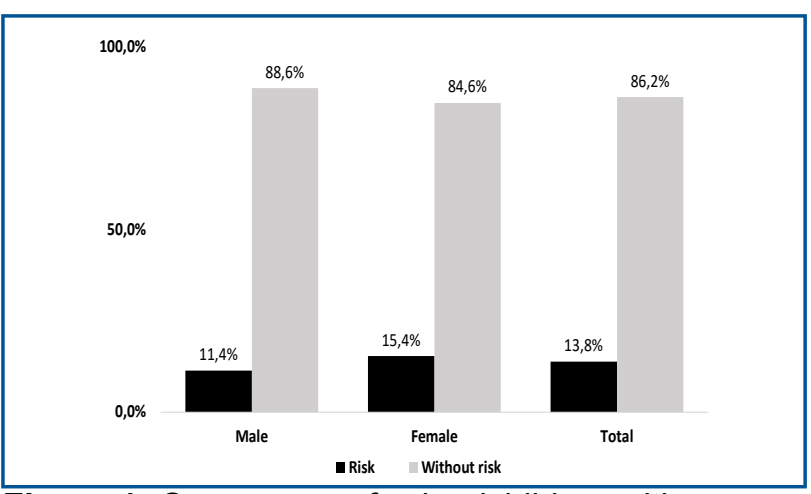

Figure 1: Occurrence of schoolchildren with metabolic risk

Table 1: Description of the characteristics of the 176 schoolchildren. Passo Fundo, Rio Grande do Sul, Brazil.

\begin{tabular}{|c|c|c|c|c|c|c|}
\hline \multirow[b]{2}{*}{ Categorical Variables } & \multicolumn{2}{|c|}{ Male $n=(70)$} & \multicolumn{2}{|c|}{ Female $n=(104)$} & \multicolumn{2}{|c|}{ Total $n=(174)$} \\
\hline & $\mathbf{N}$ & $\%$ & $\mathbf{N}$ & $\%$ & $\mathbf{n}$ & $\%$ \\
\hline \multicolumn{7}{|l|}{ Age group (years) } \\
\hline 14 to 15 & 22 & 31.4 & 41 & 39.4 & 63 & 33.2 \\
\hline 16 to 18 & 48 & 68.6 & 63 & 60.6 & 111 & 63.8 \\
\hline \multicolumn{7}{|l|}{ Region } \\
\hline Centre & 18 & 25.7 & 14 & 13.5 & 32 & 18.4 \\
\hline North & 16 & 22.9 & 22 & 21.2 & 38 & 21.8 \\
\hline South & 11 & 15.7 & 26 & 25.0 & 37 & 21.3 \\
\hline East & 13 & 18.6 & 20 & 19.2 & 33 & 19.0 \\
\hline West & 12 & 17.1 & 22 & 21.2 & 34 & 19.5 \\
\hline Continuous Variables & \multicolumn{2}{|c|}{ Average (SD) } & \multicolumn{2}{|c|}{ Average (SD) } & \multicolumn{2}{|c|}{ Average (SD) } \\
\hline Waist & \multicolumn{2}{|c|}{$72.83(10.11)$} & \multicolumn{2}{|c|}{$68.57(8.76)$} & \multicolumn{2}{|c|}{$70.28(9.53)$} \\
\hline Stature & \multicolumn{2}{|c|}{$171.62(7.54)$} & \multicolumn{2}{|c|}{$159.11(5.03)$} & \multicolumn{2}{|c|}{$164.14(8.70)$} \\
\hline $\mathrm{WH} \mathrm{HR}^{*}$ & \multicolumn{2}{|c|}{$0.42(0.05)$} & \multicolumn{2}{|c|}{$0.43(0.05)$} & \multicolumn{2}{|c|}{$0.42(0.05)$} \\
\hline
\end{tabular}

$\mathrm{n}$ : absolute sample value; \%: proportional sample value; *: waist-to-height ratio (WHtR).

\section{DISCUSSION}

The results showed approximately $14 \%$ of the metabolic risk, with no differences between the sexes ( $15 \%$ female and $11 \%$ male). The data point to a worrying scenario, aimed at the child population and adolescents have been developing early patterns of harmful behavior ${ }^{6}$. In addition, metabolic disorders are a problem of the adult population, there is evidence about risk factors for cardiometabolic diseases have their origin in childhood ${ }^{16}$.

Corroborating these findings, a study conducted in Spain with adolescents aged 11 to 17 years indicated a metabolic risk of $14.3 \%$. However, when comparing the results for the sexes, the data point in the opposite direction, indicating a higher occurrence in males $(20 \%)$ than in females $(8.7 \%)^{17}$. Nevertheless, in Poland, the risk found was lower, totaling $10 \%$, with $11 \%$ being female and $9 \%$ male. However, this study was developed with children between 7 and 12 years of age ${ }^{18}$.

In this way, these occurrences are found between 9\% and $14 \%$ in European countries. In the United States, in a trend study conducted for nine years with children and adolescents, the risk rates ranged from $32 \%$ to $36.4 \%{ }^{19}$. The high cardiometabolic health risk indexes presented can be explained due to the sedentary lifestyle, inadequate diet and physical inactivity, which are recurrent behaviors in the world population ${ }^{6}$. Since physical inactivity and sedentary lifestyle reduce energy expenditure, which when associated with high food intake may increase WC and cardiometabolic risk factors.

In Brazil, where these behaviors are increasingly present $^{20}$, the screening for the determination of early metabolic risk is extremely relevant so that from this can be developed intervention programs for prevention and health promotion of schoolchildren. However, studies from this perspective use WHtR. In Pernambuco state, Brazil, children and adolescents aged 10 to 14 years presented a metabolic risk of $12.6 \%, 14.6 \%$ for males and $11.2 \%$ for females ${ }^{21}$. However, in a study with adolescents from Paraná, who used the WC evaluation for risk assessment, these values increased to $18 \%$ in males and $27 \%$ in females ${ }^{22}$.

The divergences found in the literature may be associated with the different methods and cutoff points used. In addition, other variables may influence health risk indicators, such as sexual maturation, diet and lifestyle ${ }^{18,22}$. The importance of anthropometric indicators related to abdominal adiposity is also highlighted, as they are associated with cardiometabolic risk markers such as 
low HDL, elevated triglycerides, sedentary lifestyle and $\mathrm{MS}^{3,23}$.

Among the anthropometric indicators, the most widely recognized and used in epidemiological studies is BMI, which indicates general body fat. WC is a widely used measure in clinical practice for abdominal fat determination, being one of the variables used in the current definition of MS. The waist-hip ratio (WHtR) is also reported by estimating the amount of central fat as well as the conicity index ${ }^{24}$. More recently, the WHtR has been used to evaluate the proportion of abdominal fat by the individual's height ${ }^{11}$. It is also worth noting that in the young population, this screening tool becomes relevant for the following reasons: the possibility of evaluating more students; the population is in full process of body development and the early identification of the risk to health.

Ashwell and Hsieh ${ }^{11}$ pointed out some reasons why this method should be used, among which stand out: WHtR is more sensitive than BMI as an early warning of health risk; WHtR measurement and calculation is easier and cheaper than BMI; the use of WHtR allows the use of the same reference values for children, adolescents and adults. In addition, a systematic review showed that from the studies involving more than 300,000 adults, the WHtR was the best predictor for the detection of metabolic risk factors, in relation to $\mathrm{WC}$ and $\mathrm{BMI}^{25}$. Likewise, studies with children and adolescents indicated that the WHtR (area under the ROC curve of 0.83), when compared to BMI, WC (areas under the ROC curve of 0.79) and the ROC curve of 0.80 ) provides better estimates of metabolic risk $^{24,26}$.
In view of these aspects, it is pointed out that this study contributes to the field of public health. Considering that it was possible to make a diagnosis of the occurrence of risk to the health of schoolchildren. From this, intervention programs can be formulated that stimulate the improvement of the habits of life, consequently bringing health benefits. In addition, another relevance is that it provides subsidies to trace a metabolic risk profile in a city of Rio Grande do Sul, Brazil, where no knowledge of this is known about the use of WHtR, which is characterized as a non-invasive and easy applicability.

Despite the relevance of these results, some limitations must be taken into account. The cross-sectional design used does not allow the determination of cause and effect. In addition, the size and characteristics of the sample make it difficult to extrapolate the results to other populations, since only the students of the public school system were analyzed.

Therefore, the use of waist and height ratioWHtR as a noninvasive marker for the diagnosis of metabolic risk indicated a high occurrence in schoolchildren in public schools. The use of this method is important because it allows the evaluation of a greater number of schoolchildren and the early identification.

\section{Acknowledgement}

National Council for Scientific and Technological Development (CNPq) and Coordination of Superior Level Staff Improvement (CAPES).

\section{REFERENCES}

1. Ogden CL, Carrol MD, Kit BK, Flegal KM. Prevalence of Obesity and Trends in Body Mass Index Among US Children and Adolescents, 1999-2010. J Am Med Assoc. 2012;307(5):483. DOI: http://dx.doi.org/10.1001/jama.2012.40

2. Pereira-Lancha LO, Campos-Ferraz PL, Lancha AH Jr. Obesity: considerations about etiology, metabolism, and the use of experimental models. Diabetes Metab Syndr Obes. 2012;5:75-87. DOI: http://dx.doi.org/10.2147/DMSO.S25026

3. Andersen LB, Lauersen JB, Brond JC, Anderssen SA, Sardinha LB, Steene-Johannessen J, et al. A new approach to define and diagnose cardiometabolic disorder in children. J Diabetes Res. 2015. DOI: http://dx.doi.org/10.1155/2015/539835

4. Juonala M, Juhola J, Magnussen CG, Wurtz P, Viikari JSA, Thomson R, et al. Childhood environmental and genetic predictors of adulthood obesity: the cardiovascular risk in young Finns Study. J Clin Endocrinol Metab. 2011;96(9):1542-9. DOI: http://dx.doi.org/10.1210/jc.2011-1243

5. Barros MVG, Nahas MV, Hallal PC, Farias Junior JC, Florindo AA, Barros SSH. Effectiveness of a school-based intervention on physical activity for high school students in Brazil: the Saude na Boa project. J Phys Act Health. 2009;6(2):163-9.

6. Kahan D, Mckenzie TL. The Potential and Reality of Physical Education in Controlling Overweight and Obesity. Am J Public Health. 2015;105(4):4-11. DOI: http://dx.doi.org/10.2105/AJPH.2014.302355

7. Oliveira LCV, Braga FCC, Lemes VB, Dias AF, Brand C, Mello JB, et al. Effect of na intervention in Physical education classes on health related levels of physical fitness in youth. Rev Bras Ativ Fís Saúde. 2017;22(1):46-53. DOI: http://dx.doi.org/10.12820/rbafs.v.22n1p46-53

8. Sardinha LB, Santos DA, Silva AM, Grøntved A, Andersen LB, Ekelund U. A comparison between BMI, Waist Circumference, and Waist-To-Height Ratio for identifying cardio-metabolic risk in children and adolescents. PLoS One. 2016;11(2): e0149351. DOI: http://dx.doi.org/10.1371/journal.pone.0149351 
9. Okada R, Yasuda Y, Tsushita K, Wakai K, Hamajima N, Matsuo S. Upper-normal waist circumference is a risk marker for metabolic syndrome in normal-weight subjects. Nutr Metab Cardiovasc Dis. 2016;26(1):67-76. DOI: http://dx.doi.org/10.1016/j.numecd.2015.10.001

10. El Mabchour A, Delisle H, Vilgrain C, Larco P, Sodjinou R, Batal M. Specific cut-off points for waist circumference and waist-to-height ratio as predictors of cardiometabolic risk in Black subjects: a cross-sectional study in Benin and Haiti. Diabetes Metab Syndr Obes. 2015;8:513-23. DOI: http://dx.doi.org/10.2147/DMSO.S88893

11. Ashwell M, Hsieh SD. Six reasons why the waist-to-height ratio is a rapid and effective global indicator for health risks of obesity and how its use could simplify the international public health message on obesity. Int J Food Sci Nutr. 2005;56(5):303-7. DOI: http://dx.doi.org/10.1080/09637480500195066

12. Browning LM, Hsieh SD, Ashwell M. A systematic review of waist-to-height ratio as a screening tool for the prediction of cardiovascular disease and diabetes: 0.5 could be a suitable global boundary value. Nutr Res Rev. 2010;23(2):247-69. DOI: http://dx.doi.org/10.1017/S0954422410000144

13. Gaya ACA, Garlipp D, Silva M, Et A. Ciências do movimento humano: Introdução à metodologia da pesquisa. Artmed, 2008.

14. Callaway CW, Chumlea WC, Bouchard C, Himes JH, Lohman TG, Martin AD, et al. Circumferences. In: Lohman TG, Roche AF, Martorell R, editors. Anthropometric standardization reference manual. Champaign: Human Kinetics Books; 1991.

15. Gaya A, Lemos A, Gaya A, Teixeira D, Pinheiro E, Moreira R. Projeto Esporte Brasil (PROESP-Br). Manual de testes e avaliação. 2012; p.1-20.

16. Andersen LB, Harro M, Sardinha LB, Froberg K, Ekelund U, Brage S, et al. Physical activity and clustered cardiovascular risk in children: a cross-sectional study. Lancet. 2006;368(9532):299-304. DOI: http://dx.doi.org/10.1016/S0140-6736(06)69075-2

17. Schröder H, Ribas L, Koebnick C, Funtikova A, Gomez SF, Fíto M, et al. Prevalence of abdominal obesity in Spanish children and adolescents. Do we need waist circumference measurements in pediatric practice? PLoS One. 2014;9(1):e87549. DOI: http://dx.doi.org/10.1371/journal.pone.0087549

18. Suder A, Janusz M, Jagielski P, Głodzik J, Pałka T, Cisoń T, et al. Prevalence and risk factors of abdominal obesity in Polish rural children. Homo. 2015;66(4):357-68. DOI: http://dx.doi.org/10.1016/j.jchb.2014.09.008

19. Xi B, Mi J, Zhao M, Zhang T, Jia C, Li J, et al. Trends in abdominal obesity among us children and adolescents. Pediatrics. 2014;134(2):334-9. DOI: http://dx.doi.org/10.1542/peds.2014-0970

20. Carson V, Tremblay MS, Chaput JP, Chastin SF. Associations between sleep duration, sedentary time, physical activity, and health indicators among Canadian children and youth using compositional analyses. Appl Physiol Nutr Metab. 2016;41(6 Suppl.3):294-302. DOI: http://dx.doi.org/10.1139/apnm-2016-0026

21. Pinto ICS, Arruda IKG, Diniz AS, Cavalcanti AMTS. Prevalence of overweight and abdominal obesity according to anthropometric parameters and the association with sexual maturation in adolescent schoolchildren. Cad Saúde Pública. 2010;26(9):1727-37. DOI: http://dx.doi.org/10.1590/S0102-311X2010000900006

22. Moraes AC, Falcão MC. Lifestyle factors and socioeconomic variables associated with abdominal obesity in Brazilian adolescents. Ann Hum Biol. 2013;40(1):1-8. DOI: http://dx.doi.org/10.3109/03014460.2012.745900

23. Carvalho CA, Fonseca PCA, Barbosa JB, Machado SP, Santos AM, Silva AAM. Associação entre fatores de risco cardiovascular e indicadores antropométricos de obesidade em universitários de São Luís, Maranhão, Brasil. Cien Saúde Coletiva. 2015;20(2):479-90. DOI: http://dx.doi.org/10.1590/1413-81232015202.02342014

24. Taylor RW, Jones IE, Williams SM, Goulding A. Evaluation of waist circumference, waist to hip ratio, and the conicity index as screening tools for high trunk fat mass, as measured by dual energy X-ray absorptiometry in children aged 3-19y. Am J Clin Nutr. 2000;72(2):490-5. DOI: http://dx.doi.org/10.1093/ajcn/72.2.490

25. Ashwell M, Gunn P, Gibson S. Waist-to-height ratio is a better screening tool than waist circumference and BMI for adult cardiometabolic risk factors: Systematic review and meta-analysis. Obes Rev. 2012;13(3):275-86. DOI: http://dx.doi.org/10.1111/j.1467-789X.2011.00952.x

26. Ribeiro-Silva RC, Florence TCM, Conceição-Machado MEP, Fernandes GB, Couto $\mathrm{RD}$. Anthropometric indicators for prediction of metabolic syndrome in children and adolescents: a population-based study. Rev Bras Saude Mater Infant. 2014;14(2):173-81. DOI: http://dx.doi.org/10.1590/S1519-38292014000200007 


\section{Resumo}

Introdução: As desordens metabólicas na infância e adolescência vem aumentando consideravelmente. Dessa forma, destaca-se a importância da realização de um diagnóstico precoce.

Objetivo: Analisar a ocorrência de risco metabólico utilizando marcador não invasivo em escolares.

Métodos: Trata-se de um estudo descritivo com abordagem quantitativa, com amostra aleatória de 174 escolares (70 meninos e 104 meninas) de 10 escolas estaduais de ensino médio na cidade de Passo Fundo-RS-Brasil. A estatura $(\mathrm{cm})$ foi verificada de acordo com os procedimentos do Projeto esporte Brasil e a circunferência da cintura $(\mathrm{cm})$ foi mensurada com uma fita métrica flexível e inelástica. A partir disso foi calculada a razão entre cintura e estatura, que leva em conta a proporção de gordura abdominal pela estatura do indivíduo, considerando o ponto de corte de Ashwell \& Hsieh. Para análise de dados utilizou-se estatística descritiva e qui-quadrado.

Resultados: O risco metabólico dos escolares foi de 13,8\%, quando estratificado por sexo as ocorrências foram de $11,4 \%$ para o masculino e $15,4 \%$ para o feminino, porém não houve diferença significativa entre os sexos $\left(X^{2}=0,54 ; p=0,45\right)$.

Conclusão: $A$ utilização de marcadores não invasivos para o diagnóstico de risco metabólico indicou uma ocorrência elevada em escolares, sendo que as meninas apresentaram maior risco. Destaca-se a importância da utilização desse método, pois possibilita a avaliação de maior número de escolares e a identificação precoce do risco à saúde. Além de ser um método de baixo custo e de fácil aplicabilidade.

Palavras-chave: adolescentes, antropometria, saúde. 